\title{
Gunung Gangsir dan Wilayah Di Sekitarnya
}

Oleh :

Dra, Ririet Suriandari, M.Hum

Balai Pelestarian Peninggalan Purbakala Samarinda

\section{Abstract:}

Gunung Gangsir Temple, one of the glorious temple in East Java that made of bricks. There's two opinion about the period. One said that it is from Sindok's period, and the others said it is from Majapabitperiod.

As we know, the architectur and decoration of the temple looks similarly with Prambanan Temple. The difference only on its material; Prambanan temple is made of stone, and Gunung Gangsir made of bricks with its unique size like plaque and big block.

Gunung Gangsir Temple is around with amount of wells. Formerly, in 1993 there are 7 wells that function till that time. In 2007, that wells only 4 with 1 dry-mell include. It is caused by the increasing people houses around Gunung Gangsir Temple.

Temple and its environmental can be research by matching the data in the inscription. In this case, the writer will match the connection between Cunggrang inscription with localization of three building that mentioned in that inscription.

\section{Pendahuluan}

Candi Gunung Gangsir terletak di Dusun Kebon Candi, Desa Gunung Gangsir, Kecamatan Beji, Kabupaten Pasuruan, pada posisi 7035'12.6" LS dan 112043'59,9" BT. Secara geografis, Candi Gunung Gangsir terletak di dataran rendah, sekitar $13 \mathrm{~km}$ di sebelah timur Gunung Penanggungan. Candi berdiri di atas permukan tanah seluas $1500 \mathrm{~m} 2$ yang dibatasi kawat berduri yang Sekaligus merupakan batas tanah milik purbakala, yang dikelilingi oleh jalan desa pada keempat sisinya. Lingkungan di sekitarnya merupakan rumah yang padat berjarak 10-20 $\mathrm{m}$ dari bangunan

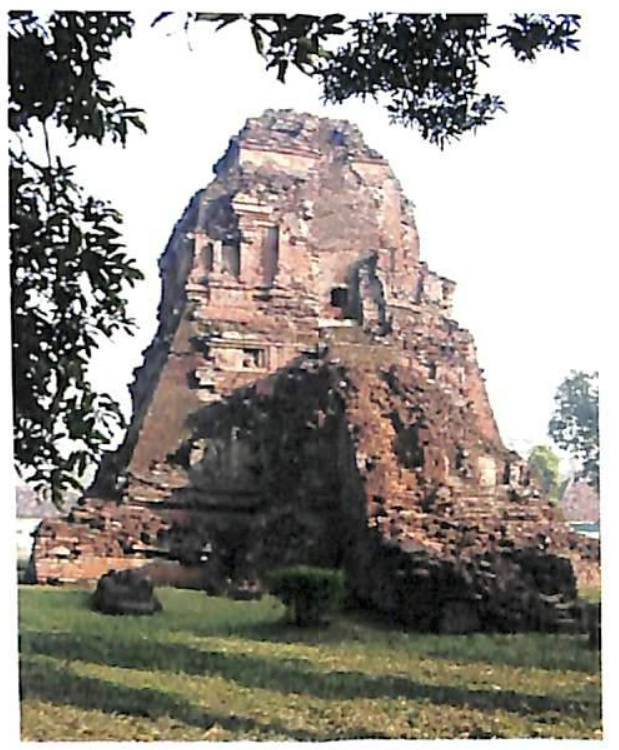

candi.

Secara umum, di wilayah Kabupaten Pasuruan banyak sekali terdapat benda cagar budaya tidak bergerak dari berbagai masa, sejak masa Sindok hingga Majapahit seperti misalnya Candi Gunung Gangsir, Petirtaan Belahan (dari masa Sindok), situs Pancasara/Raos Pacinan, Candi Pari, Candi Kebo Ireng (dari masa Majapahit), lereng Gunung Penanggungan dari masa Airlangga hingga Majapahit dan masih banyak lagi yang lainnya. Nama Gunung Gangsir berasal dari cerita rakyat yang masih berkembang di masyarakat, yang berarti menggangsir untuk mendapatkan sesuatu. Pada dinding sisi utara terdapat bekas lubang (bhs Jawa: digangsir) sehingga kemudian disebut Candi Gunung Gangsir.

Mengenai masalah penjamanan Candi Gunung Gangsir, ada beberapa pendapat. Yang pertama adalah bahwa Gunung Gangsir berasal dari masa Sindok. Pendapat yang lain mengatakan berasal dari masa Majapahit. Pendapat pertama ini didasarkan pada bentuk arsitektur yang mirip arsitektur Candi Prambanan di Jawa Tengah. Menurut NJ Krom, Candi Gunung Gangsir dihubungkan dengan masa peralihan perkembangan kesenian dari gaya Jawa Tengah ke Jawa Timur. Kesenian Jawa Timur berkembang secara berevolusi di antara kesenian Jawa Tengah dan Jawa Timur, sehingga sulit untuk menentukan kapan terjadi perubahan dengan gaya seni tersebut, karena tidak ada dukungan gaya arkeologis yang kuat. Krom menyebutkan ada tiga monumen yang menunjukkan bahwa keterkaitan antara kesenian Jawa Tengah dan Jawa Timur. Ketiga monument tersebut adalah Candi Loro Jonggrang (terletak di Prambanan Jawa Tengah), Candi Gunung Gangsir dan Gapura Belahan (Keduanya di Pasuruan, Jawa Timur). Sedangkan pendapat kedua mendasarkan pada lokasi candi yang terletak di Pasuruan. Pada umumnya candi-candi di sekitar Candi Gunung Gangsir tersebut berasal dari masa Majapahit, seperti misalnya Candi Pari yang terletak sekitar $6 \mathrm{~km}$ di sebelah barat Candi Gunung Gangsir.

Di dekat Candi Gunung Gangsir terdapat sebuah kolam, sekitar $1 \mathrm{~km}$ di sebelah barat dava. Pada saat ini ini dinding-dinding 
kolam tersebut telah diberi pagar baru. Data arkeologis yang tertinggal berupa sisa-sisa batu besar yang digunakan sebagai lantai dasar kolam. Batu-batu besar tersebut tampaknya kuna. (Ririet, 2003). Sangat disayangkan tidak ada satupun prasasti panjang maupun pendek untuk melacak penanggalannya. Satu-satunya sumber tertulis yang cukup membantu adalah Nagarakrtagama. Di dalam pupuh 17:11a dan pupuh 18:6a diceritakan bahwa Hayam Wuruk dalam perjalanannya dari Kapulungan menuju ke timur singgah beberapa saat di kolam yang terletak di sebelah timur Kapulungan kuna: "prapteng dharma ring prapancasara tumuluy dhateng i kapulungan siramgil (sampai di Dharma Pancasara kemudian memasuki Kapulungan, di situ bermalam), Ndah prapteng pancuran mungkur atiki larining syandanenjing marayyan (sampai di Pancuran Mungkur, iringan berhenti pada pagi hari) (Sidomulyo, 2007:34,36).

Berdasarkan pada toponim dan temuan arkeologis, Kapulungan ole h $\mathrm{Hadi} \mathrm{Sidomulyo}$ diidentifikasikan dengan Kejapanan sekarang (Sidomulyo, 2007: 36-7). Diperkirakan bahwa kolam tersebut adalah Pancuran Mungkur yang sekarang telah berubah nama menjadi Sumbersono di Dusun Sumberkepuh Desa Gunung Gangsir. Kondisi terakhir, dalam rencana pembuatan jalan tol untuk mengalihkan jalan tol Porong yang terkena dampak lapindo, maka di sekitar kolam tersebut direncanakan akan dibuat jalan tol.

Secara arsitektural, hipotesa bahwa Candi Gunung Gangsir berasal dari masa Sindok didukung oleh ukuran bata. Telah diketahui bersama, bahwa ukuran bata juga dapat menunjukkan penanggalan secara nisbi. Ada satu hipotesa bahwa ukuran bata yang semakin besar, menandakan semakin tua usia bangunan. Sebaliknya semakin kecil ukuran bata maka semakin muda usia bangunan. Ukuran bata di Candi Gunung Gangsir adalah $9 \times 26 \times 39 \mathrm{~cm}$, dan $9 \times 26 \times 47 \mathrm{~cm}$. Sedangkan bata berelief berbentuk plaque berukuran lebih besar lagi. Sementara itu ukuran bata dari masa Majapahit pada umumnya adalah 6 $\mathrm{X} 18 \times 32 \mathrm{~cm}$ dan $10 \times 23 \times 39 \mathrm{~cm}$.

\section{Kajian intern}

Kajian intern dilakukan terhadap aspek-aspek pada Candi Gunung Gangsir, yaitu pembacaan dan interpretasi prasasti pendek, interpretasi peripih, interpretasi motif-motif hias/relief dan cara buatnya pada Candi Gunung Gangsir.

Temuan prasasti pendek pada bata lapis 2 sisi kiri/selatan bidang tegak tangga. Setelah dilakukan pengamatan secara seksama pada masing-masing bata, pada bidang tegak sisi kiri tangga pada bata lapis 2 terdapat prasasti pendek yang ditulis dalam huruf Jawa Kuna. Tulisan tersebut diguratkan pada dua sisi bata bagian strek yang tersusun berdampingan. Berdasarkan bentuknya, hurufhuruf tersebut berbentuk cenderung bulat seperti tipe huruf tersebut merupakan gaya khas huruf tipe Sindok, dan terdapat kuncir/serif. Kuncir Jawa Tengahan termasuk Sindok. Huruf yang masih dapat terbaca terdapat pada bata sisi timur sebanyak 2 buah, berbunyi pāra dan dari jejak-jejaknya tampak samar-samar satu buah huruf yang berbunyi ma setelah kata pāra Sehingga dengan demikian kat tersebut dapat dibaca pārama Sangat disayangkan bahwasany. pada bata sisi barat yang jumlal huruf-hurufnya lebih banyak memenuhi seluruh posisi strek bata ada bekas-bekas penghalusan sehingga huruf-huruf tersebut tidak dapat terbaca lagi. Namun dari jejak jejaknya tampak adanya goresan layar, dan suku.

Pārama berasal dari kata Sanskerta berarti yang paling utama atau yang tertinggi (Zoetmulder. 1995: 764). Di dalam konsep agama Hindu, pārama merupakan istilah untuk menyebut Tuhan sebagai Dzat yang tertinggi. Dengan demikian ada kemungkinan prasasti pendek tersebut seperti halnya prasasti-prasasti pendek dari daerah lainnya, berfungsi sebagai petunjuk. Prasasti pendek penunjuk tersebut antara lain terdapat di Candi Borobudur (Kab. Magelang), Candi Penataran (Kab. Blitar), Candi Plaosan Lor (Kab. Klaten), dan Candi Pari (Kab. Sidoarjo). Dengan a da na tulisan pārama menunjukkan bahwa tempat di sekitar tulisan tersebut merupakan tempat paling suci atau paling utama yang berfungsi sebagai brahmasthana candi, yaitu titik perpotongan dua garis diagonal denah candi. Hal ini seperti halnya yang terjadi di Candi Prambanan, 
kedudukan brahmasthana juga di sudut tenggara di dekat penampil anak tangga.

Secara lokasional, tempat penulisan kata pārama dengan penempatan dua peripih yang telah ditemukan pada tahun 2006 (laporan bulanan kegiatan p e m u g r a n Candi Gunung Gangsir bulan Agustus 2006), $\mathrm{s}$ a $\mathrm{ng}$ a $\mathrm{t} \mathrm{lah}$ berdekatan, yaitu sekitar 50 $c \mathrm{~m} \quad \mathrm{p}$ a d a kedalaman 40 c $\mathrm{m}$ d a r i

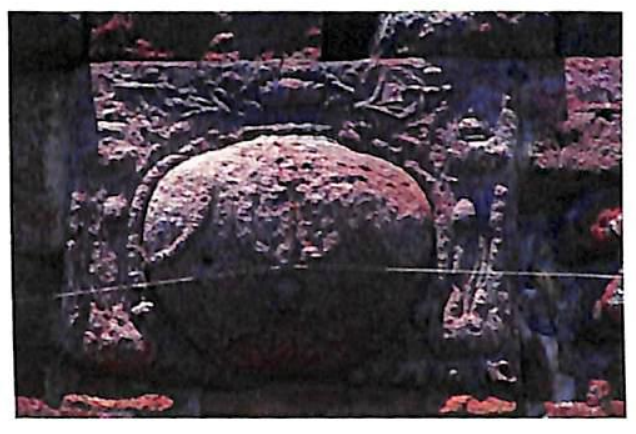
ma e veld t.

Dengan demikian dapat diajukan satu asumsi bahwa ada hubungan kontekstual antara prasasti pendek tersebut dengan penempatan peripih.

Pertimbangan lokasi ini sangat berarti. Mengacu pada candicandi yang sejaman dengan Candi Gunung Gangsir, yaitu Candi Prambanan yang terletak di Prambanan DIY, sangat mungkin bahwa brahmasthana Candi Gunung Gangsir tidak berada tepat di tengah candi, melainkan pada sudut tenggara di dekat tangga naik. Hal ini telah dibuktikan dengan adanya temuan dua buah peripih bata yang berisi lembaran emas berbentuk sri vastu, bentuk-bentuk binatang yang belum selesai pengerjaannya, padma (isi peripih I), kura-kura / kurma dan kambing (isi peripih II).

Bentuk padma dan kurakura ini apabila dikaji secara mitologis, maka kedua benda tersebut adalah sebagai salah satu manifestasi Wisnu. Kura-kura adalah salah satu awatara Wisnu yang pertama. Sedangkan Padma adalah bunga suci yang biasa dibawa oleh Laksmi sebagai istri Wisnu, sehingga dia disebut pula dengan padmestitha. Dengan demikian tampak bahwa aliran keagamaan yang mendasari bangunan ini adalah Waisnawa. Binatang kambing sering digambarkan dalam mangkuk zodiak. Di dalam penanggalan Jawa $\mathrm{K} u \mathrm{n}$ a , kambing/wrsabh a melambangkan bintang Aries yang berlaku pada bulan MaretApril.

Di dalam konsep agama Hindu, isi peripih dianggap sebagai kesatuan 5 elemen sebagai perwujudan dewa-dewa dalam agama Hindu, yang berfungsi untuk "menghidupkan" candi. Candi itu sendiri merupakan tempat ibadah bagi umatnya untuk melakukan pemujaan. Di dalam formasi penempatan dewa-dewa, hal tersebut sesuai dengan arah mata angin (dikpalaka), dengan pusatnya berada di tengah. Masing-masing adalah sebelah utara untuk Wisnu, sebelah selatan untuk Brahma, sebelah timur untuk Iswara, sebelah barat untuk Mahadewata dan tengah untuk Siwa. Secara ringkasnya, unsur-unsur dewa in i dimanifestasikan dalam bentuk logam yang mewakili warna masingmasing dewa, yaitu: besi untuk Wisnu, tembaga untuk Brahma, perak untuk Iswara, emas untuk Mahadewata (Donder, 2001: 78-79).

Di dalam kepercayaan Hindu, candi merupakan replika Gunung Mahameru atau replika kosmos (alam semesta). Dengan demikian candi harus didirikan di lingkungan yang suci. ()leh karena itu suatu tempat yang akan dipakai untuk mendirikan candi harus disucikan terlebih dahulu. Tempat itu kemudian diberi tanda dengan sembilan patok, satu di pusat, delapan masing-masing di keempat sudutnya dan pada tengah sisisisinya (Soekmono, 1977: 232-235).

Isi peripih tersebut dimasukkan ke dalam wadah/peripih. Adapun bahan peripih bermacam-macam, yaitu logam, batu atau tanah liat bakar. Pada Candi Gunung Gangsir, kedua peripih yang ada terbuat dari bata yang diberi cekungan berbentuk segi empat di tengah sebagai tempat isi peripih.

Keberadaan peripih di sebelah tenggara menurut pembagian ruang dalam skala mikro kosmos (triangga) dalam agama Hindu merupakan tempat yang nisthaning uttama (Munandar, 2007:4-5). Sementara itu dalam susunan Astadikpalaka, arah tenggara merupakan tempat kedudukan dewa Agni (Munandar, 2007). Seperti halnya dewa-dewa lainnya yang mempunyai wahana, maka wahana Agni adalah domba. Dengan demikian, ada korelasi yang saling menunjang antara konsep dengan kenyataan yang diterapkan dalam penempatan peripih di Candi Gunung Gangsir. Sementara itu di dalam Rg Weda, kambing merupakan hewan persembahan dewi kesuburan dan kemakmuran dengan pemujaan kepada sakti (Wiryosaputro, 1957:21).

Hal ini sesuai dengan isi peripih kedua, yaitu di antaranya terdapat kambing sebanyak 2 lembar. Adapun bentuk yang lain adalah kura-kura sebagai simbol awatara Wisnu, yaitu kurma awatara. Sedangkan padma merupakan simbol Siwa. Sementara itu isi peripih pertama menunjukkan adanya pengaruh Waisnawa yang kuat. Hal ini ditunjukkan oleh dominannya bentuk-bentuk isi peripih yang mengacu pada awatara 
Wisnu, yaitu 3 lembar bentuk segi empat (sri vastu), 2 lembar bentuk yang belum selesai dapat diidentifikasi sebagai ikan, 1 lembar bentuk yang belum selesai dapat diidentifikasi sebagai babi, dan 1 lembar bentuk yang belum selesai dapat diidentifikasi sebagai binatang bertaring, serta 1 buah bentuk padma sebagai perlambang Siwa ( L a p or a n $\mathrm{K}$ e gi a $\mathrm{t}$ a $\mathrm{n}$ Pemugaran Candi Gunung Gangsir bulan Juli tahun 2006). Bentuk sri vastu ini merupakan $1 \mathrm{a} \mathrm{m} \mathrm{b}$ a $\mathrm{ng}$ Wisnu. Sri

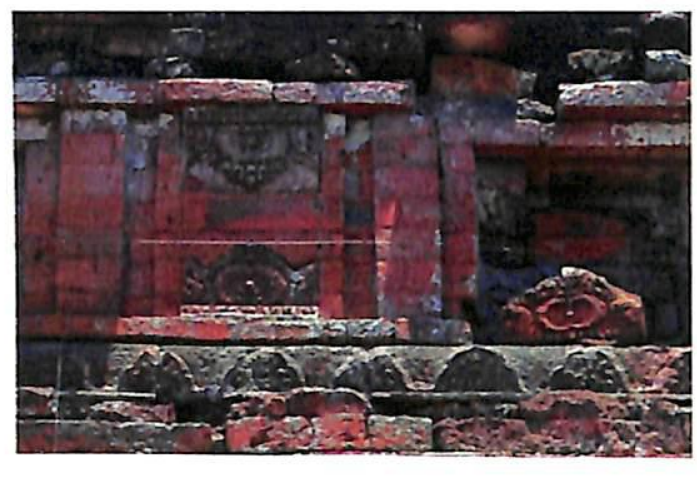

Sehingga dengan demikian dapat diduga bahwa ada pentahapan dalam pembangunan anak tangga tersebut, yang dilakukan sebanyak empat kali (4 tahap). Pertimbangan pentahapan pembangunan ini adalah alasan sudut elevasi tangga yang terlalu terjal sehingga $\mathrm{k}$ e m u d i a $\mathrm{n}$ d i l a k u k a penambahan $u \quad n \quad t \quad u \quad k$ mengurangi keterjalannya. Hal dilakukan sampai empat kali. Dengan demikian dirasa perlu untuk "menghidupkan vastu selain

berbentuk segi empat biasanya berbentuk jajaran genjang atau belah ketupat. Bentuk ikan dapat diidentifikasikan sebagai matsya dalam awatara Wisnu dan bentuk babi dapat diidentifikasikan sebagai babi hutan atau waraha di dalam awatara Wisnu.

Adapun alasan adanya 2 peripih dalam satu tempat, menunjukkan adanya dua kali proses "menghidupkan" candi. Secara arsitektural ada data yang mendukung hipotesa ini. Ketika dilakukan pembongkaran penampil tangga pada tahun 2006 (laporan bulanan pemugaran Candi Gunung Gangsir bulan Juli-Agustus 2006), ada petunjuk adanya pentahapan pembangunan pada anak-anak tangga tersebut. Apabila dilihat dari samping pada struktur anak tangga ada 4 cara pemasangan struktur penampil tangga yang bareh/tidak ada ikatan, yang ditandai oleh nat bata membentuk garis lurus vertikal. Sementara itu pada bidangbidang yang lain susunan antar bata selalu saling berkait demi alasan
" kembali candi sehingga dilakukan upacara untuk kedua kalinya dengan menanam lagi peripih kedua.

Selama ini apabila memperbincangkan masalah peripih, yang ditekankan pada umumnya hanya pada isi peripih yang berupa emas. Sedangkan isi peripih lainnya yang berfungsi sebagai pelengkap berupa biji-bijian, beras, dsb, biasanya terabaikan. Pelengkap ini bermacam-macam, yaitu kayu cendana, biji-bijian, beras, uang kepeng, permata, minyak dan benang (Donder, 2001:81-92). Fungsi dan arti simbolis masingmasing adalah:

kayu cendana berfungsi sebagai pengganti logam/timah untuk ditulisi;

rempah-rempah berfungsi untuk penghangat yang memberi daya hidup, karena h i d u p me merluk a n energi/panas. Secara sakala niskala rempah-rempah berfungsi sebagai pemanas dalam menjaga kehidupan yang suci pada bangunan suci; biji-bijian/kacang-kacangar berupa biji-bijian hasil bum yang dapat dikonsumsi manusi sebagai makanan untul dipersembahkan kepada Tuhar YME sebagai wujud dari ras bhakti manusia sebagai ciptaan Tuhan. Biji-bijian juga wakil dar segala buah-buahan; sementara itu buah adalah simbol ketulusan dan kebulatan hati. Biji-bijian tersebut antara lain kacang merah, hijau, jagung, kacang hitam;

Beras, filosofinya adalah bahwa oleh Tuhan persembahan disampaikan kepada Tuhan karena Tuhan itu sendiri adalah persembahan (Bhagavad Gita IV: 24; XV: 14), yang artinya bahwa semuanya adalah Tuhan (sarva kala idam brahman). Adapun syarat-syaratnya biji beras harus utuh, berkualitas, dan merupakan perlambang warna dari para dewa; putih untuk Siwa, kuning untuk Mahadewa, merah untuk Brahma, hitam untuk Wisnu; uang kepeng berfungsi sebagai persembahan sekaligus lambang/simbol manifestasi Tuhan. Penggunaannya adalah berdasarkan angka-angka yang melambangkan sifat dan jumlah para dewa. Uang kepeng merupakan campuran 4 warna (emas, perak, tembaga, dll) yang merupakan lambang panca dewata;

permata: pada umumnya yang digunakan adalah jenis mirah; minyak biasa dan minyak wangi: ibarat sebagai zat lemak dalam tubuh; minyak untuk mencuci logam keramat; minyak catur atau 4 jenis minyak yaitu kelapa be julit, sangket, giri dan sudamala;

benang: sarana pengikat pembungkus dan pengikat peripih (terdiri dari 3 
warna/tridhatu, catur warna); wadah: berfungsi untuk tempat benda-benda tersebut, terbuat dari logam, batu, atau tanah liat bakar.

Selain peripih yang ditemukan pada tahun 2006 tersebut, pada sekitar awal tahun 1990-an, di dalam kompleks situs Candi Gunung Gangsir, di sebelah barat candi, pernah ditemukan isi peripih satu lembar emas berbentuk gajah yang sekarang disimpan di BP3 Jawa Timur. Di dalam mitologi agama Hindu dan Budha, gajah merupakan simbol kekuatan atau kesuburan. Selain itu gajah juga dianggap sebagai dewa yang dapat memberikan curah hujan, sebagai simbol kekuatan, keseimbangan dan perlindungan (Iyer, 1970: 87; Kadarsan, 1977: 310). Di dalam filosofi India, gajah merupakan unsur alam yang tidak mudah rapuh dan sebagai makhluk surga. Dalam kaitannya dengan kedewataan, gajah sebagai wahana dari Laksmi (Purniti, 1990: 72). Sementara itu Laksmi merupakan salah satu sakti Wisnu.

Gajah dalam agama Budha merupakan simbol turunnya Sang Budha Gautama dari sorga ke bumi, ketika dewi Maya ibu Sang Budha yang sedang mengandung bermimpi seekor gajah putih terbang mengelilingi perutnya dan masuk ke rahimnya dari arah kiri (Liebert, 1976: 210). Dalam mitologi Budha disebutkan bahwa Aksobhya duduk pada dua ekor gajah biru. Dalam cerita Jataka, Sang Bodhisatwa dilahirkan dalam bentuk gajah (candhaka-jataka) dan Silavana Naga Jataka (Piyasilo, 1989: 47).

Hiasan yang ada pada Candi Gunung Gangsir berdasarkan fungsinya dapat dibedakan menjadi dua, yaitu dekoratif dan religius.
Fungsi dekoratif antara lain adalah hiasan sulur-suluran yang menghiasi bangunan candi. Sulur-suluran berfungsi dekoratif menjadikan bangunan suci agama Hindu Budha penuh ragam hias sulur-suluran, dibuat dengan bentuk indah, ukiran yang halus, dan terkesan naturalis, sehingga membuat bangunan candi menjadi megah dan indah (Soekmono, 1992: 100). Sulursuluran tersebut dibuat dengan kesan subur dan rimbun, dianggap sebagai simbol gambaran alam kedewataan dan berkaitan dengan filsafat kehidupan manusia dan siklus kosmis, serta pandangan terhadap alam la in y a ng menguasai dunia dengan $\mathrm{keraja}$ a kedewataan (Nurhakim, 1990: 82).

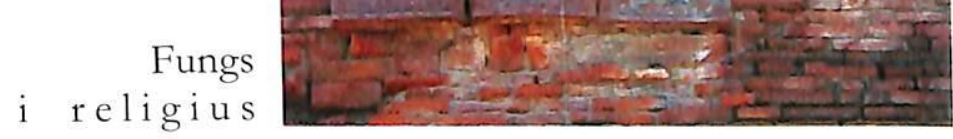

adalah motif

hias keagamaan. Motif hias keagamaan ini merupakan bagian dari prinsip bhakti, yaitu rasa kasih dan menyerah pada dewa-dewa (Santiko, 1987: 71). Menurut Bosch, sulur-sulur tersebut bukan merupakan tangkai melainkan akarakar tinggal bunga teratai yang melilit di dalam lumpur dan di dalam air. Pada akar tinggal tersebut tumbuh buku-buku atau ruas-ruas, di tempat itu tumbuh tangkaitangkai, daun dan bunga. Ruas inilah yang utama sebagai lambang kesuburan (Bosch, 1948: 9). Bentuk sulur-suluran yang melingkarlingkar tiada awal dan akhirnya melambangkan kebahagiaan, kemujuran, dan kesuburan yang bersifat abadi tanpa awal dan akhir. Selain itu lingkaran juga melambangkan kedewataan dan kesucian yang bersifat agung. Di dalam bentuk seni arca maupun seni hias, bentuk lingkaran dapat disejajarkan dengan prabhamandala yang di dalam mitologi India sebagai lambang kendaraan dewa (Liebert, 1976: 271).

Motif hias yang lain adalah bentuk-bentuk bunga teratai yang beragam pada Candi Gunung Gangsir. Teratai tersebut antara lain terdapat pada dinding selatan, berupa relief teratai dengan daun lancip. Teratai yang digambarkan demikian adalah termasuk dalam kategori kumuda. Kumuda adalah sebutan untuk teratai biru (Nymphea stella). Ciri teratai biru adalah daun tidak lebar, bunga tidak pernah terbuka, d a u n n y a membengkok ke bawah, bunga hampir tidak muncul di air (Piyasilo,

1989: 40-1).

Sedangkan pada dinding utara terdapat relief tinggi (haute relief) menggambarkan seorang perempuan yang sedang hamil muda, tangan kirinya memegang teratai putih (Nymphea lotus). Ciri teratai putih adalah bunga lebar dan runcing, daun tidak bergelombang, daun bunga mengapung. Ada satu pertanyaan yang kemudian muncul, apakah relief ini merupakan tanda bahwa candi ini bersifat Waisnawa. Asumsi yang dapat diajukan adalah bahwa relief pada sisi utara tersebut menggambarkan relief padmesthita, yaitu Sri sebagai sakti Wisnu yang digambarkan sedang membawa teratai. Di dalam ikonografi Hindu, Sri adalah istri Wisnu yang lain disamping Laksmi. Secara ikonografis kadang Sri dan 


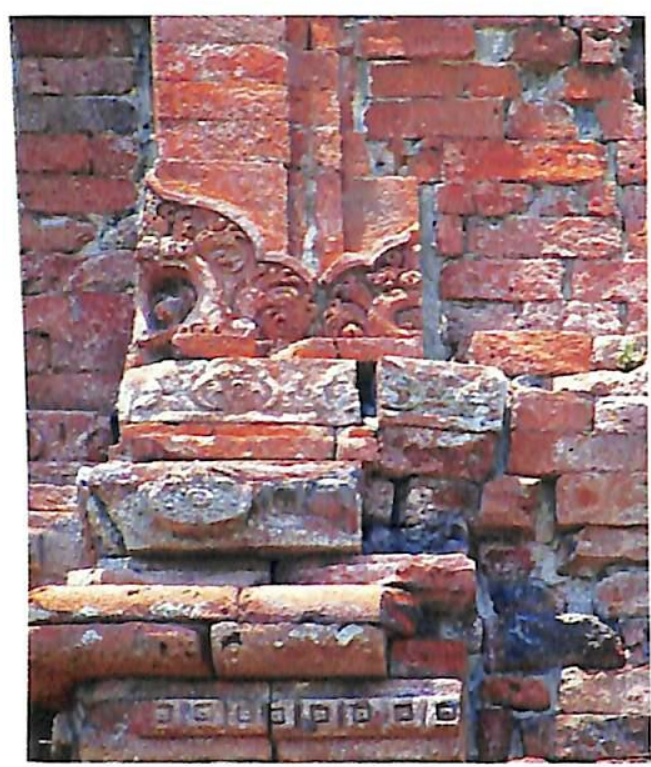

Laksmi diarcakan bersama-sama, kadang salah satu. Di dalam perkembangannya, Sri diyakini sebagai dewi kesuburan dalam kaitannya dengan pertanian.

Motif hias teratai sangat populer penggunaannya pada masa Hindu Budha. Di dalam kebudayaan Hindu Budha motif hias teratai selalu dihubungkan dengan filsafat ketuhanan dan sering digunakan simbol yang mempunyai arti kesucian, lambang kelahiran, maupun kehidupan (Zimmer, 1962: 22). Bunga teratai merupakan lambang kehidupan semua dewa atau juga merupakan lambang dari alam semesta sebagai tanda keagungan alam ciptaan Brahma. Brahma sering disebut juga Kamalasana, sejak ia duduk di atas bunga teratai yang tumbuh dari pusar Wisnu. Di dalam Rg Weda disebut Prajapati. Selain itu juga disebut Svayambu dan Hiranyagarbha, yaitu benih kehidupan, penciptaan dan kemakmuran (Gupte, 1972:26).

Kajian intern yang lain adalah relief motif kalpataru yang terdapat pada tubuh candi. Bentuk kalpataru pada Candi Gunung Gansir mirip dengan kalpataru pada
Candi Prambanan. Kalpataru pada umumnya digambarkan berupa pohon yang keluar dari vas yang dihiasi dengan untaian manikmanik dan permata. Tepat di atas pohon terdapat sebuah payung/chattra lebar dan datar berhias sulur. Di antara pohon dan chattra, di kiri kanan terdapat sepasang burung yang digambarkan sedang terbang. Chattra merupakan lambang regalia/kekuasaan dan hanya digunakan secara tertentu pula. Dengan adanya chattra di atas kalpataru, maka dapat diasumsikan bahwa kalpataru dianggap sebagai pohon yang mempunyai arti khusus. Kalpataru memang dianggap sebagai pohon kehidupan. Kalpataru untuk pertama kalinya dalam sejarah kuna Indonesia dijumpai dalam prasasti Yupa peninggalan Raja Mulawarman dari kerajaan Kutai pada abad IV M. Kalpataru kemudian dimanifestasikan melalui sifat-sifat raja seperti sifat-sifat kebaikannya, senantiasa memberi perlindungan, pengayoman dan memberi sedekah kepada rakyat (Abdulrazak, 1991: 39). Di Jawa Tengah pada abad VIII-X M pengaruh India ini masih sangat kuat, sehingga menjadikan kalpataru sebagai salah satu motif hias yang cukup penting pada bangunan candi pada saat itu, seperti Candi Borobudur, Mendut, Pawon, Sojiwan, dan Prambanan. Penggambaran kalpataru bermacam-macam, dari segi penempatan maupun unsur penyertanya yang berbeda-beda. Unsur penyerta pohon kalpataru itu antara lain: chattra (payung), binatang pengapit, burung-burung di atas pohon, kantung harta, hiasan manik-manik dan mutiara (Ratnawati, 1989, Ichwan, 1999: 95).

\footnotetext{
Demikian pula relief kalpataru pada Candi Gunung
}

Gangsir digambarkan dengan unsu penyerta yang berbeda-beda pula Satu hal yang menonjol pad kalpataru dari Candi Gunung Gangsir adalah penggambaran pohon kalpataru yang penuh dengan teratai merah yang sedang mekar. Adapun penempatan relief kalpataru ini di kiri dan kanan tangga masuk.

Penempatan relief pada tubuh candi selain mempunyai fungsi tertentu, juga agar penampilan bangunan kelihatan rapi dan enak dipandang. Di samping itu juga harus terlihat indah dan dapat tampil lebih menonjol dalam arti menjadi pusat perhatian. Penempatan relief dalam rangka tujuan tersebut harus ditempatkan pada tempat yang strategis atau pada ketinggian yang mendaki, seperti pada kaki, pipi tangga atau tubuh candi. Penempatan yang demikian akan tampil jauh mengesankan jika dibandingkan pada atap candi atau tempat yang kurang strategis yang membuat relief akan kelihatan tenggelam dan kurang mengesankan (Kusen, 1991-2: 80). Kajian intern yang lain adalah relief binatang. Pada dasarnya relief binatang pada candi merupakan relief cerita yang mengandung ungkapan-ungkapan dari para seniman kepada para penikmat melalui hasil karya tersebut. Cerita biasanya diambil dari karya kesusasteraan dari India yang sudah digubah kembali oleh para pujangga Jawa Kuna yang disesuaikan dengan sosiokultural masyarakat pada saat itu. Cerita-cerita tersebut memberikan pendidikan ajaranajaran agama, moral dan etika (Pigeaud, 1967: 45). Karya sastra tersebut banyak dipahatkan pada bangunan suci kuna seperti pada candi (Kempers, 1976: 221).

Ketika pada tahun 2006 
dilakukan pembongkaran penampil tangga, pada lapis 011 di bawah permukaan tanah ditemukan bata yang bagian dalam/bawahnya digores relief semacam burung Garuda (laporan bulanan pemugaran Candi Gunung Gangsir bulan Juli 2006). Burung garuda sering disebut pula dengan Supana (suvana). Di Siam (Thailand) garuda disamakan dengan angsa (hamsa), sedangkan garuda dalam mitologi Melayu Kuno disebut dengan rajawali. Di Tibet garuda dipandang sebagai manusia burung, dimana berbadan manusia dan berkepala burung dengan paruh besar, mempunyai tiga mata. Dalam mandala, garuda merupakan lambang kebenaran individu atau Vairocana (Piyasilo, 1989: 136). Yang menjadi pertanyaan adalah, mengapa relief dengan teknik gores tersebut diletakkan dalam posisi terbalik, sehingga justru relief menghadap ke bawah. Ada kemungkinan bahwa relief tersebut ada yang salah/tidak sesuai sehingga digunakan sebagai bata isian pada lapis 011 di bawah pemukaan penampil tangga.

Motif hias yang lain yang cukup menarik adalah adanya salah

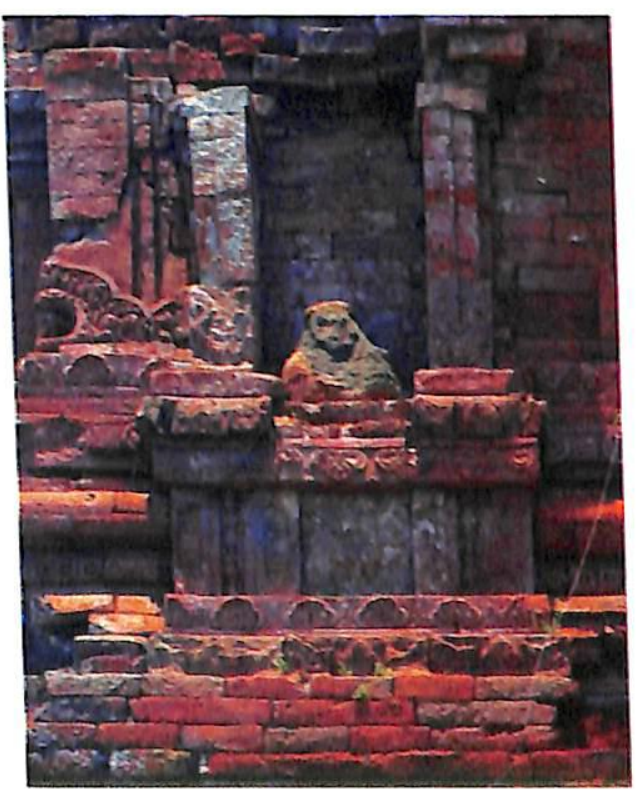

satu bata yang berhias relief motif batik. Motif tersebut berupa jajaran genjang dengan lingkaran di tengahnya. Apabila dibandingkan dengan relief batik di Candi Prambanan, maka juga terdapat beberapa motif batik, antara lain kawung dan jajaran genjang. Reliefrelief tersebut pada Candi Prambanan ditempatkan di sekitar tangga naik, dengan posisi vertikal. Apabila mengacu pada Candi Prambanan, maka motif batik pada Candi Gunung Gangsir tersebut juga dapat berada di sekitar tangga. Namun demikian, hal ini masih perlu penelitian dan anastilosis lebih lanjut.

Kajian intern lainnya yang dilakukan adalah mengamati teknik buat relief-relief yang terdapat pada bagian tubuh candi. Dari pengamatan secara kasat mata, bahan penyusun candi ini terbuat dari bata dengan ukuran yang sangat besar. Demikian pula untuk batabata berelief dibuat dengan satu ukuran besar seperti plaque (Hasan Djafar, 2007; Srivastava, 1993). Bentuk-bentuk panil relief yang dipahatkan pada bata besar ini memang lazim digunakan pada candi-candi di India awal, seperti misalnya di Orissa dan Nandangarh. Bentuk panil tersebut biasa disebut dengan plaque. Cara buat plaque dengan ukuran yang demikian besar, tentunya diperlukan suatu keahlian khusus untuk membuatnya, mulai dari cara membuat adonan, mencetak, mengeringkan hingga membakarnya. Apabila adonan kurang kompak unsur-unsur tanahnya, maka akan terbentuk pori-pori karena masing-masing agregat bahan penyusun bata kurang menyatu, sehingga ketika dikeringkan akan menjadi pecahpecah. Demikian pula, dalam membuat ukuran cetakan harus diperhatikan benar, karena calon bata itu akan menyusut apabila mengering. Di dalam pengeringan, calon bata sebaiknya tidak terkena panas matahari langsung, karena proses penguapan yang terlalu cepat akan membuat bata retak-retak. Terakhir, di dalam pembakaran harus diperhatikan tungku pembuatan dengan cermat agar pembakaran terjadi dengan sempurna dalam arti api dapat menyebar secara merata. Apabila peroses pembakaran tidak sempurna maka akan terjadi reduksi CO2 yang mengakibatkan terjadi vitrifikasi terhadap bata yang berakibat pada terbentuknya warnawarna hitam akibat keluarnya gas CO2 secara tidak bagus, sehingga secara tampilan bata tersebut kurang bagus (Miksic, 1990).

Ada satu asumsi yang dapat diajukan dalam hal ukuran bata yang demikian besar. Secara kronologis, Candi Gunung Gangsir merupakan candi dari masa Sindok, yang masanya berdekatan dengan pembangunan Candi Prambanan. Hal ini didukung oleh bentuk maupun motif hiasnya (Marijke Klokke, 2002). Dengan demikian, ada kemungkinan bahwa pembuat candi ini masih terbawa pada pembuatan candi berbahan batu, sehingga plaque-plaque yang berhiaspun dibuat dalam ukuran besar, seperti halnya hiasan panilpanil di Candi Prambanan. Walaupun telah disadari pula oleh para pembuatnya bahwa cara pembuatan plaque maupun bata penyusun candi apabila dibuat dalam ukuran besar memerlukan cara vang cukup jeli dan hati-hati.

\section{Kajian ekstern}

Kajian ekstern yang dilakukan dapat dipilah menjadi dua. Yang pertama adalah 
hubungan candi dengan lingkungan di sekitarnya, yang masih termasuk dalam satu desa. Sedangkan yang kedua adalah hubungan candi dengan wilayah yang lebih luas lagi, yaitu dikaitkan dengan candi-candi di sekitarnya dan lingkungan alamnya. Kajian ekstern yang dimaksudkan adalah bahwa Candi Gunung Gangsir ditempatkan sebagai satu sistem yang berada satu kompleks (compound) dalam area yang lebih luas. Secara kontekstual, Candi Gunung Gangsir berada dalam wilayah di bawah deretan pegunungan Arjuna, Anjasmoro dan Penanggungan.

Kondisi eksisting di sekitar Candi Gunung Gangsir pada saat ini adalah di sebelah utara berupa tanah rawa. Demikian pula di sebelah timur. Sementara itu ketinggian air tanah adalah sekitar $1,20 \mathrm{~m}$ dari permukaan tanah, sehingga ketika tanah digali sedalam kurang lebih 1 meter maka air sudah keluar dengan d e rasnya. $\mathrm{K}$ o n d i s i lingkungan di sekitar Candi $\mathrm{G}$ u n u n g Gangsir pada saat ini terletak di tanah datar. Pada bentangan yang luas, di sebelah selatan candi terdapat bukit-bukit, yang kemudian mengarah pada lereng gunung Penanggungan. Sedangkan di sebelah utara terdapat sungai Wrati yang menuju ke laut, dan sekarang dijadikan batas antara Kabupaten Pasuruan dan kabupaten Sidoarjo. Pada bentangan kecil, di sebelah barat terdapat saluran Nyangkring, di sebelah timur terdapat saluran Panggang Lele dan di sebelah selatan terdapat saluran Ngurawan.
Hubungan kontekstual dengan lingkungan terdekatnya adalah dikaitkan dengan sumursumur kuna yang banyak ditemukan di sekitarnya hingga radius 150 meter. Sumur-sumur tersebut sudah pernah diobservasi oleh BP3 Jawa Timur pada tahun 1993. Hasil pendataan pada tahun tersebut adalah ditemukan sumur sebanyak 7 buah. Dari sumur sejumlah itu, 6 buah berbentuk silindrik dan 1 buah berbentuk bujur sangkar. Sumursumur tersebut berada di lingkungan rumah penduduk dan di tengah tegalan atau sawah. Adapun sumur yang masih dipergunakan penduduk tinggal 6 buah. Pada tahun 2002 ketika diadakan kegiatan studi teknis arkeologi sebagai langkah awal sebelum dilakukan pemugaran, dilakukan lagi pendataan sumur-sumur tersebut untuk mengecek keberadaannya, apabila ada perubahan. Ternyata dari jumlah tersebut tinggal 5 buah, dan yang masih digunakan penduduk 4 buah. Saat ini, pada tahun 2007 ,
ketika sedang berjalan kegiatan pemugaran tahap I $\mathrm{V}, \mathrm{ketika}$ $\mathrm{d}$ i a d a k a n pengecekan kembali sumursumur tersebut, $\mathrm{maka}$ sudah menyusut lagi tinggal 4 buah. Untuk itu perlu dilakukan tindakan pengamanan, untuk mencegah berkurangnya sumur-sumur tersebut.

Melihat banyaknya sumur yang ada beserta distribusinya, dapat diperkirakan bahwa mungkin dahulu di wilayah sekitar Candi Gunung Gangsir sudah merupakan pemukiman yang relatif cukup padat. Hanya saja perlu diteliti lebih mendalam lagi, siapa sajakah yang bertempat tinggal di sekitar candi Adakah klasifikasi sosial di situ? Karena di samping penduduk bias yang bertugas mengelola candi. tentu saja harus ada tempat tinggal untuk para pendeta yang mengurus dan memimpin upacara keagamaan. Untuk melengkapi pertanyaanpertanyan tersebut dapat dilakukan pencocokan dengan data dari sumber tertulis. Prasasti sebagai sumber tertulis tidak hanya memberi data historis, akan tetapi juga dapat mengungkap data kemasyarakatan, ekonomi, keagamaan dan bahkan lingkungan secara luas (Boechari, 1977: 319 . 331).

Hubungan kontekstual yang lebih luas lagi adalah bahwasanya Candi Gunung Gangsir dikaitkan dengan pewilayahan yang terjadi pada masa Jawa Kuno, khususnya pada sekitar abad XI. Apabila berbicara masalah candi, maka hal ini tidak dapat lepas dari lingkungan tempat berdirinya suatu candi (Boechari, 1977). Karena candi sebagai sebuah tempat kegiatan agama, maka tentunya di sekitar candi juga terdapat pemukiman beserta dengan penduduknya sebagai pelaku kegiatan keagamaan tersebut. Dengan demikian, dapat dikatakan bahwa candi beserta lingkungannya dapat dianggap sebagai satu sistem yang saling b e rka i $\mathrm{dal}$ a $\mathrm{m}$ s a t u compound/convinience. Dengan demikian maka haruslah ada titik pusatnya. Secara geologis dan kosmis, maka Gunung Penanggungan dapat dianggap sebagai pusatnya. Di dalam Prasasti C ung grang, Gun ung Penanggungan disebut sebagai Gunung Pawitra yang dianggap suci dan berfungsi sebagai Mahameru.

Sekitar $7 \mathrm{~km}$ di sebelah 
selatan Candi Gunung Gangsir, di Dusun Sukci Desa Bulusari Kecamatan Gempol terdapat prasasti Cunggrang yang dituliskan pada kedua sisi batu. Pada saat ini, prasasti ini berdiri sendiri, terdapat satu temuan penyerta yang lain berupa lingga semu. Lingga semu tersebut pada awalnya berasal dari daerah sekitar prasasti itu berada, yaitu sekitar 500 meter di sebelah barat laut. Berdasarkan cerita penduduk dan juru pelihara, dulu di sekitar prasasti terdapat batu yang mereka sebut batu patok, yang dapat diasumsikan sebagai lingga semu juga. Lingga semu ini berfungsi sebagai batas desa. Ketika BP3 Jawa Timur mengadakan kegiatan registrasi di Kab. Pasuruan, di dekat pasar Kapulungan (sekitar $5 \mathrm{~km}$ di sebelah tenggara Desa Bulusari) terdapat lingga semu.

Prasasti Cunggrang ada dua buah. Satu buah dituliskan pada batu yang sekarang masih insitu di Dusun Sukci, sedangkan yang lain dituliskan pada lempengan perunggu yang sekarang disimpan di Gereja Kayutangan Malang.

Prasasti Cunggrang secara ringkas berisi tentang penetapan sima atas desa Cunggrang yang termasuk wilayah Bawang di bawah kekuasaan Wahuta Wungkal, dipersembahkan sebagai punpunan kepada Sang Hyang Dharmasrama di Pawitra, nama kuno untuk Gunung Penanggungan, dan Sang Hyang Prasada Silunglung dari Sang Sidha Dewatra Rakryan Bawang, ayah dari nenek raja, atas perintah Sri Maharaja Rake Hino Pu Sindok, untuk permaisuri Sindok yang bernama Sri Parameswari Dyah Kbi. Prasasti ini berangka tahun 851 Saka pada bulan Asuji. Adapun sebab diturunkannya prasasti ini karena adanya pengalihan pajak untuk membiayai pemeliharaan pertapaan, prasadha dan petirtaan.
Kewajiban Wahuta Wungkal adalah mengurusi pertapaan dan prasada dan memperbaiki pemandian suci di Pawitra.

Apabila lebih dicermati lagi isi prasasti Cunggrang, tampak bahwa ada dua hal penetapan sima, yaitu desa Cunggrang dan sawah pakarungan. Desa Cunggrang disebutkan dalam kaitannya dengan $\mathrm{keb}$ e ra d a a n bangunan suci yang harus dipelihara. $\mathrm{D}$ e $\mathrm{n}$ g a $\mathrm{n}$ demikian tentu s a j a D es a Cunggrang ini b e r u p a pe mukima n,

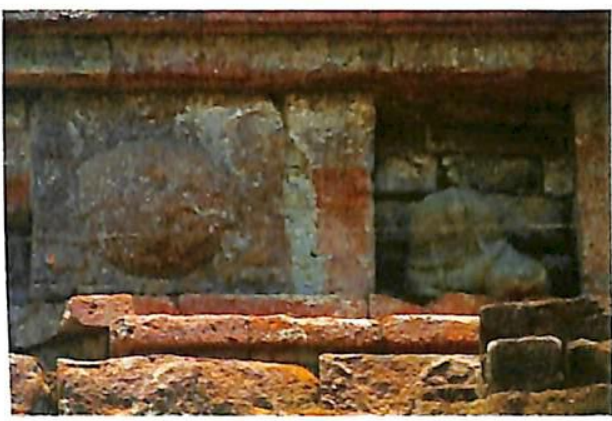
$\mathrm{d} i \mathrm{~m}$ a $\mathrm{n}$ a penduduk yang berada di dalamnya mempunyai kewajiban menjaga, merawat, membersihkan dan memperbaiki apabila ada yang rusak bangunan suci tersebut. Adalah logis, bahwa pengelola bangunan suci tersebut tinggal berdekatan dengan bangunan suci. $\mathrm{Hal}$ ini didukung oleh temuan arkeologis berupa sumur-sumur yang berada di sekitar candi. Selain itu juga ada sawah pakarungan yang ditetapkan sebagai sima untuk menghasilkan biaya bagi pemujaan bhatara di prasada di pertapaan di Tirtha pada tanggal 3 tiap bulan dan biaya persembahan caru setiap hari (Boechari, 1977: 323-324).

Untuk mendukung kelangsungan hidup para pengelola candi, maka juga diperhatikan pula pemenuhan kebutuhan pokok, antara lain makan. Pada prasasti Cunggrang selain penetapan sima desa Cunggrang juga disebut sawah pakarungan. Sawah pakarungan dapat ditafsirkan sebagai sawah dan pakarungan, yaitu tempat peternakan babi.
Hasil dari kedua kegiatan tersebut digunakan untuk menunjang kegiatan keagamaan dan kehidupan masyarakat di sekitar candi, dimana penghidupan masyarakat pada waktu itu pada umumnya bertumpu pada sektor pertanian dan peternakan. Kehidupan bertani ini masih nampak berlangsung sampai sekarang. Penduduk sekitar candi sampai saat ini masih menanam padi di sekitar c a n d i d a n bahkan beberapa sumur tersebut berada di areal sawah. Sekitar $200 \mathrm{~m}$ di sebelah utara candi terdapat areal sawah yang selalu mengandung air. Ada kemungkinan daerah ini semula berupa rawa-rawa, sebagaimana kadang daerah rawapun dapat ditetapkan menjadi sima demi kelangsungan bangunan suci (Boechari, 1977: 328-329).

Apalagi melihat intensitas upacara yang dilakukan cukup padat, yaitu setiap tanggal 3 tiap bulannya dan caru setiap hari. Ini menunjukkan bahwa pendeta tidak boleh tinggal terlalu jauh dari bangunan suci. Demikian pula tempat tinggal para budak yang berkewajiban merawat bangunan suci. Bahkan tempattempat melakukan upacara keagaman dengan segenap persiapannya. Dengan penelitian arkeologi melalui ekskavasi diharapkan dapat dikaji secara lebih dalam tentang pemukiman ini, misalnya kemungkinan adanya pola-pola pemukiman. Secara lebih luas lagi akan dapat dikaji pola keletakan candi dalam lingkungan kesatuan teritorialnya, sehingga akan diketahui pewilavahan pada abad XI di sekitar Candi Gunung Gangsir. 
Dari telaah isi Prasasti Cunggrang tersebut di atas, tampak bahwa penetapan sebuah desa menjadi sima tidak berarti bahwa desa tersebut bebas pajak dan pungutan sama sekali. Bedanya adalah bahwa hasil pungutan pajak dan denda dari tanah sima digunakan untuk berbagai macam keperluan bagi bangunan suci, antara lain biaya pela ks a n a $\mathrm{n}$ bermacam sajisajian, upacara pemujaan terhadap bhatara di dalamnya $\mathrm{d}$ a $\mathrm{n}$ u n t u k pemelihara $n$ bangunan.

\section{Status sima}

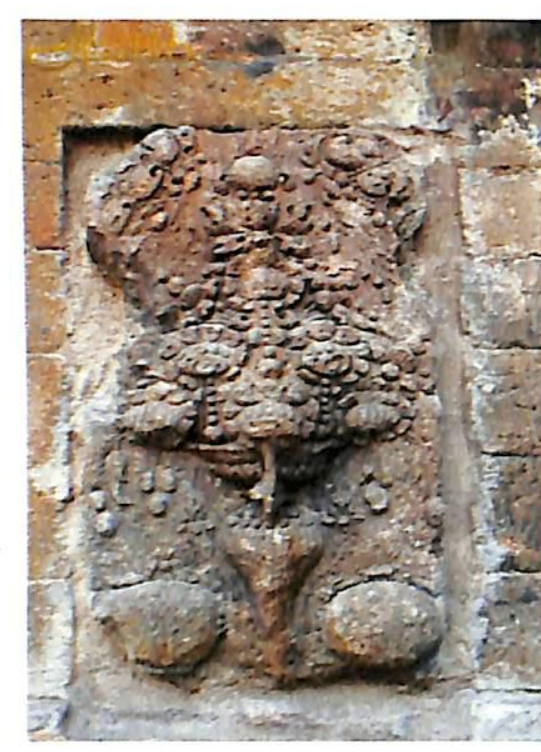

tersebut adalah swatantra, dalam arti tidak boleh dimasuki oleh patih, wahuta, nayaka, pratyaya, pangkur, tawan, tirip, rama dan semua yang termasuk dalam mangilala drwya haji. Adapun semua denda-denda yang termasuk dalam sukha duhkha dikuasai oleh bhatara pada bangunan suci tersebut. Sementara itu bagi pajak perdagangan ada aturan sejumlah tertentu yang digunakan untuk keperluan bangunan suci, sedangkan yang lainnya masuk dalam kas kerajaan. Sedangkan pajak usaha ada 2 ketentuan. Kadang pajak tersebut dikuasai bhatara atau harus dibagi tiga dengan ketentuan sepertiga masuk sima/bangunan suci, sepertiga untuk perbendaharaan kerajaan, dan sepertiga dikuasai bhatara di bangunan suci yang bersangkutan (Boechari, 1977: 325). Dengan demikian nampak bahwa ada suatu organisasi yang mengatur semua mekanisme tersebut sehingga dapat berjalan lancar.
Prasasti Cunggrang juga menyebutkan adanya tiga buah bangunan suci, yaitu pertapaan (dharma rama), candi (prasada silunglung) dan petirtaan (sang hyang tirtha). Oleh para ahli, petirtaan itu diidentikkan dengan Belahan. Sedangkan $c$ a n d y a n g d i m a k s u d, mungkinkah Candi Gunung Gangsir? Penulis mencoba me ne lu sur i hubungan Candi Gunung Gangsir dengan Belahan dan $G \quad u \quad n \quad u \quad n \quad g$ Penanggungan. Di atas kertas, antara ketiga lokasi tersebut dapat ditarik satu garis lurus dengan orientasi kemiringan sekitar 66-670 dari arah barat dengan jarak sekitar $8,9 \mathrm{~km}$.

Menurut Th. A Resink Petirtaan Belahan telah ada sejak Raja Sindok pada abad X Masehi dan bukanlah merupakan pendharmaan Raja Airlangga seperti yang diasumsikan oleh ahliahli lain. Adapun dasar penelitiannya adalah dari segi arsitektural, ornamentasi dan prasasti. Prasasti Cunggrang ditemukan tidak jauh dari Gapura Belahan. Prasasti Cunggrang sebagaimana disebutkan di atas, menyebutkan adanya tiga buah bangunan, yaitu dharma rama (pertapaan), prasada silunglung sebagai tempat pendharmaan rakryan Bawang, dan Sang Hyang Tirtha Pancuran, terletak pada lokasi yang sama, yaitu di Pawitra (Gunung Penanggungan). Lokasi Prasada Silunglung tidak disebutkan, tetapi ada kemungkinan Candi Gunung Gangsir. Mengingat lokasi temuan prasasti Cunggran tidak jauh dari gapura Belahar kemungkinan yang dimaksud San Hyang Tirtha Pancuran adalal Petirtaan Belahan itu sendiri, dar merupakan salah satu bangunar yang terdapat di dalam dharm rama, hal ini sesuai dengan adany. air yang dipancurkan (tirt pancuran) dari arca, yang ada $d$ petirtaan Belahan. Mengenai fungs kolam suci di dalam karya sastri disebutkan sebagai tempat untuk menyucikan diri dan memperoleh kebahagiaan bagi mereka yang dilanda kesedihan dan penat pikirannya dengan cara melakukan yoga. Jika memang benar arca Wisnu naik garuda itu berasal dar Belahan, keberadaannya justru akan memperkuat fungsi Petirtaan Belahan itu sendiri. Arca Wisnu naik garuda tersebut digambarkan dalam sikap yogasanamurti, yaitu merupakan arca yang dipuja oleh para yogin atau oleh para calon yogin (Winston, 1987; Rao, 1914). Sedangkan dharma rama sampai saat ini belum diketahui. Mengingat namanya, dharma rama ini bisa jadi merupakan tempat pertapaan. Apabila benar demikian, maka dharma rama haruslah berada di tempat yang sunyi dan pada daerah yang relatif tinggi, sehingga dengan demikian orang yang berada di dharma rama dapat mendapatkan ketenangan dalam melakukan semedi.

Dengan demikian dapat diajukan satu asumsi, bahwa dharma rama tersebut telah runtuh, pintu gerbangnya di Belahan. Sedangkan prasada silunglung untuk tempat pendharmaan rakryan Bawang adalah Candi gunung Gangsir, dan yang dimaksud dengan Sang Hyang Tirtha Pancuran sudah jelas adalah petirtaan Belahan. Dengan demikian secara kronologis, ketiga bangunan tersebut berasal dari masa 
Sindok, seperti yang telah kecil di dekat petirtaan Belahan. disampaikan oleh Resink.

\section{Penutup}

Kajian terhadap Candi Gunung Gangsir ini masih merupakan kajian awal yang penulis lakukan ketika menjadi ketua unit dalam kegiatan pemugaran Candi Gunung Gangsir pada tahun 20032005, dan 2007-2008. Banyak hal yang menarik tentang candi ini yang harus diungkapkan, karena belum begitu banyak sumber pustaka yang membahas secara mendalam, baik masalah teknis maupun dari segi arkeologisnya. Untuk itu tidak menutup kemungkinan adanya pengembangan penelitian yang dapat dilakukan oleh siapapun di masa mendatang.

Berdasarkan hiasan, segi arsitektural dan teknis pembuatan bahannya, dapat diajukan satu asumsi bahwa Candi Gunung Gangsir bisa jadi merupakan candi kerajaan dari masa Sindok sebagai ganti Candi Prambanan yang merupakan candi kerajaan dari rajaraja pendahulunya. Hal ini didukung oleh banyaknya persamaan secara garis besar antara Candi Prambanan dan Candi Gunung Gangsir.

Dalam kaitannya dengan wilayah di sekitar candi, penulis mencoba menghubungkan data sumber tertulis dengan data arkeologis. Adanya banyak BCB tidak bergerak di sekitar Candi Gunung Gangsir seperti gapura dan petirtaan Belahan besar kemungkinan merupakan tempattempat yang disebut di dalam Prasasti Cunggrang, yaitu prasadha silunglung untuk Candi Gunung Gangsir, sang hyang tirtha adalah petirtaan Belahan dan sang hyang dharma kemungkinan sudah hancur tinggal sisa-sisanya berupa gapura

\section{Daftar Pustaka}

A.M. Chowdhury, 1996, Bengal and South East Asia: Trade and Cultural Contact in the Ancient Period' dalam Ancient Trade and Cultural Contact in South East Asia. Bangkok: the office of the National Culture Commission.

Boechari, 1977, Candi dan Lingkungannya' dalam PIA I, Cibulan.

Gosta Liebert, 1975. Iconographic Dictionary of The India Religion, Study in South Asian Culture, , Leiden: EJ brill.

Gupte, RS, 1972. Iconograpby of Hindus, Budhist, and Jains, , India: DB Taraporevala Sons and Co.

Hasan Djafar, 2007 'Kompleks Percandian di Kawasan Situs Batujaya, Karawang-Jawa Barat Kajian Sejarah Budaya', Disertasi, Depok: Universitas Indonesia.

I Ketut Donder, 2001. Pancadhatu Atom, Ātma, dan Animisme (Sebuab Evolusi Konsep Tentang Sesuatu yang Amat Kecil Sebagai Asas bidup Dan kehidupan), Surabaya: Penerbit Paramita.

J.E. van Lohuizen de Leeuw, 1957 'The Ancient Buddhist Monastery at Paharpur' dalam Antiquity and Survival Vol. II No. 1, The Hague-Netherlands.

K. M. Srivastava, 1993. 'The Sites and Stucco Figurines of Nalanda' dalam Arts of Asia,23 (4) July-August, hal. 90-99.

Marijke J. Klokke, 2002. 'Candi Gunung Gangsir Gangsir a Inique Temple in East Java' dalam Friuts of Inspiration Studies in Honour of Prof. J. G. De Casparis, Groningen, Egbert Forsten.

Muhammad Ichwan, 1999. Relief Binatang pada Candi mendut, Skripsi, Denpasar: Universitas Udayana, belum diterbitkan.

Soekmono, 1977. Candi Fungsi dan pengertiannya, Jakarta: Disertasi FS UI.

T A Gopinatha Rao, Elements of Hindu Iconograpby vol I Part I, Madras: The law Printing House Mount Round.

Veronica Ion, 1967. Indian Mythology. NY: Paul Hamlyn Ltd.

Ven Piyasilo, Mandala of Five Buddhas, A Study of Buddhist Iconography and Symbolism, $\mathrm{M}$ a 1 a y s i a : $\mathrm{T} h \mathrm{e}$ Dharmafarers.

------' 'South east Asian Architecture and the Stupa of Nandangarb' dalam Atribus Asiae vol XIX, $3 / 4$ MCMLVI, PublishersAscona-Switszerland. -- 2003. Laporan Studi Teknis Arkeologis Candi Gunung Gangsir, Ririet

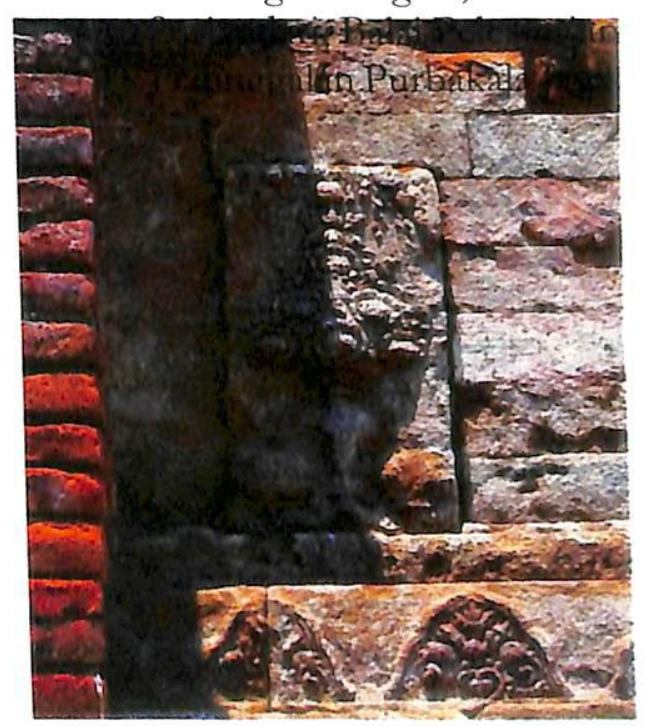

Sumber foto Candi Gunung Gangsir www.navigası.net/goart.php?a=bucaggs! 